\title{
LANDFILLS AS LONG-TERM SINKS FOR ORGANIC CARBON - AN IMPORTANT PARAMETER FOR REDUCTION OF GLOBAL ATMOSPHERIC CO2 CONCENTRATIONS
}

\author{
Torleif Bramryd \\ Michael Johansson \\ University of Lund, Sweden.
}

\begin{abstract}
Increased $\mathrm{CO}_{2}$ concentrations in the atmosphere contribute to global warming and thus disturbed meteorological balances. It is of great importance to establish carbon accumulating processes in the urban society, as the natural $\mathrm{CO}_{2}$ balancing processes are insufficient to compensate for the increasing emissions of carbon dioxide.

Controlled landfills, and different types of landfill bioreactor cells for residual wastes, play a role as long-term storage for organic carbon, and therefore, if a reliable biogas collection system is provided, counteract increased atmospheric $\mathrm{CO}_{2}$ concentrations. Landfills thus can be regarded as the anthropogenic counterpart to natural peatlands and lake sediments.

In a landfill reactor-cell, treating approximately 100000 tons of waste per year, and where the fermentation residues are left in the landfill, a long-lived organic fraction corresponding to about 45000 metric tons of carbon dioxide is long-term accumulated each year. This compensates for the annual carbon dioxide emissions from about 15000 cars, provided that each one runs $15000 \mathrm{~km}$ per year with fossil fuel.

During landfilling most of the organic carbon in fossil derived products, like plastics, synthetic rubber or textiles, a.s.o. will be brought back to long-term accumulation. As these products only to a very small extent take part in the methane gas production, the landfill gas (biogas) can be regarded as a true bio fuel. With a modern bioreactor technique almost all produced biogas can be collected in the extraction system, and emissions of methane to the atmosphere are minimized. Modern research has also shown that methane emissions from landfills are at much lower rates than earlier expected, mainly due to efficient gas collection systems but also to methane oxidizing bacteria in the surface cover layer of the landfill. As a conclusion, treatment of residual wastes in highly optimised landfill cells creates an important sink for organic carbon and a preferred "in-situ" stabilization technique before final landfilling.
\end{abstract}

\section{KEYWORDS}

Landfill; Carbon sink; Carbon accumulation; Bioreactor cell; Global $\mathrm{CO}_{2}$-concentration; Biogas. 


\section{INTRODUCTION}

During the last 150 years the atmospheric $\mathrm{CO}_{2}$ concentration has increased by almost 100 ppm compared with the pre-industrial period and in 2005 reached a value of approximately $379 \mathrm{ppm}$. The natural range of carbon dioxide concentrations over the last 650000 years is about 180-300 ppm, and thus the present values far exceed these values. Over the period 1995-2005 the average growth-rate of the atmospheric carbon dioxide concentrations was about $1.9 \mathrm{ppm}$ per year on an average. [1].

The natural $\mathrm{CO}_{2}$ balancing processes are insufficient to compensate for the increasing emissions of carbon dioxide. Thus it is of great importance to establish carbon accumulating functions in the urban society. Landfills can be regarded as the anthropogenic counterpart to natural peatlands and lake sediments, i. e. ecosystems with a capacity to accumulate organic carbon, which thus can balance the increased atmospheric concentrations of $\mathrm{CO}_{2}$.

Accumulation of organic carbon in long-lived organic matter in the urban society, like in buildings, libraries, etc is also a process that might delay the release of $\mathrm{CO}_{2}$ to the atmosphere [2, 3]. It was estimated that this accumulation in long lived products amounted to about $2.10 \times 10^{6} \mathrm{~g} \mathrm{C}$ per capita in industrialized countries and about $0.15 \times 10^{6} \mathrm{~g} \mathrm{C}$ per capita in less industrialized countries, resulting in a total sink of carbon in human houses of over $3500 \times 10^{12} \mathrm{~g}$ organic carbon [2].

Landfilling of organic carbon is one of the few available carbon accumulating processes in the human society, and landfilling can be compared to the natural peat and sediment accumulating processes in natural ecosystems [2,3].The annual accumulation of organic carbon in the World's landfills in the 1980's was estimated to around $100 \times 10^{6}$ metric tons of $\mathrm{C}[2,3]$. However due to increase of material recovery and increased incineration the resent figure is probably somewhat lower, in spite of increased waste volumes. The size of the long-term accumulated fraction depends on the conditions for decomposition in the landfill. Estimates by $[4,5]$ indicate that the fraction left for long-term accumulation in the World's landfills amounts to approximately $30 \times 10^{12} \mathrm{~g} \mathrm{C}$ per year.

Most of the organic carbon in fossil derived products, like plastics and other synthetic materials during landfilling will be brought back to long-term accumulation. As these products only to a very small extent take part in the methane gas production, the landfill gas (biogas) can be regarded as a true bio fuel [6]. In contrast to incineration, high moisture content in the waste will not decrease the yield of energy per ton of waste.

The long-lived organic material left in the fermentation residue in the landfill can, except from plastics, to a large extent be derived from lignin compounds in the waste. Lignine compounds also make up for a major part of the litter fractions creating humus under aerobic conditions. Thus the organic fraction contributing to the methane formation in an anaerobic landfill or landfill reactor cell is normally short-lived, also in a natural aerobic environment, and therefore has a short turn-over time. According to [7], about $91 \%$ of the produced methane gas can be derived from cellulose and hemicellulose compounds. The reactor cell fermentation technique thus very well conforms to the natural $\mathrm{CO}_{2}$ cycle. 
Methane has high energy content and is a good and clean fuel. With a modern bioreactor technique almost all biogas is collected in the extraction system. On the other hand, if methane would have been allowed to escape to the atmosphere it could act as a severe greenhouse gas. However, modern research has shown that the emissions from landfills are at much lower rates than earlier expected, mainly due to methane oxidizing bacteria in the surface cover layer of the landfill. Thus even if there are no biogas collection systems, the amounts of produced methane in the landfill is reduced by approximately a factor 10 in the surface layer, before it escapes to the atmosphere.

If the waste would have been incinerated, most of the organic carbon would be emitted as $\mathrm{CO}_{2}$, including carbon derived from fossil material. Due to high moisture content in municipal solid waste, energy will be consumed and $\mathrm{CO}_{2}$ produced for the evaporation of water. This contributes to the negative effects of waste incineration on the atmospheric carbon balance.

If energy production through waste incineration was replaced by biological energy extraction from waste, and if bio fuels like straw, woodchips from forest residues or energy forests were used instead, the effects on the global carbon dioxide balance could be decreased.

\section{THE POTENTIAL OF A BIOREACTOR LANDFILL AS A SINK FOR ORGANIC CARBON}

Household waste normally contains approximately $23-25 \%$ organic carbon, while industrial waste, with lower water content and normally a higher proportion of paper, wood and plastics, contains somewhat higher proportions of organic carbon. Plastics and rubber are rather unaffected by biological degradation and is left in the landfill. Under anaerobic conditions also lignine is resistant to degradation and will remain in the fermentation residue.

The total annual amount of mixed municipal and industrial waste that was landfilled in Sweden before the ban on landfilling of organic matter was inforced in Sweden in 2002, could be estimated to around $3 \times 10^{6}$ ton [8], corresponding to approximately $0.75 \times 10^{12} \mathrm{~g}$ C. Of this fraction about $0.40 \times 10^{12} \mathrm{~g}$ organic carbon can be regarded as resistant to degradation under normal landfill conditions. At the same time about $2 \times 10^{6}$ tons of waste was incinerated each year in Sweden, resulting in a release of about $0.50 \times 10^{12} \mathrm{~g} \mathrm{C}$. A fraction of about $0.30 \times 10^{12} \mathrm{~g} \mathrm{C}$ would have been more or less long-term accumulated if this amount of waste instead would have been landfilled or treated in landfill reactor cells. Today most of this long-lived carbon fraction is rapidly released to the atmosphere through incineration.

Earlier investigations with landfill gas recovery and reactor cell fermentation have shown that approximately $150-200 \mathrm{~m}^{3}$ of biogas, with $50-55 \%$ methane gas concentration, can be extracted per ton treated waste with the first generation of a reactor cell fermentation technique. With $25 \%$ organic carbon per ton household and light industrial waste, and with a

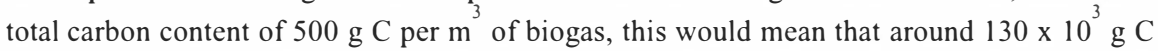
per ton originally landfilled waste should remain in the landfill after approximately 15-20 years. Of this amount lignin contributes to approximately $40-50 \times 10^{3} \mathrm{~g} \mathrm{C}$ and plastics to about $20-30 \times 10^{3} \mathrm{~g} \mathrm{C}$. The remaining fraction, about $40-50 \times 10^{3} \mathrm{~g}$ could theoretically be 
converted to biogas after improving and optimizing the fermentation technique in e.g. landfill reactorcells (biocells). The amount of total organic carbon discharged from landfill reactorcells through the leachates is small in comparison to the losses through the biogas, around 3-6\% [9]. Accordingly, approximately $70-90 \times 10^{3} \mathrm{~g}$ organic carbon per ton household waste would remain in the fermentation residue after advanced fermentation in landfill bioreactors, compared to about $130 \times 10^{3} \mathrm{~g} \mathrm{C}$ with the present technique for optimized biogas production. In a normal well managed landfill with biogas extraction probably around $150 \times 10^{3} \mathrm{~g} \mathrm{C}$ is long term accumulated per ton landfilled waste.

The calculations above indicate that around $60 \%$ of the organic carbon in the solid waste remains in the fermentation residue after normal landfilling, while about $30-50 \%$ of the original carbon content would remain after optimized landfill reactor cell (biocell) treatment. These figures are somewhat lower compared to some earlier estimates based on landfill fermentation studies, e.g. $[4,7,10]$, which range from $60-75 \%$ for the remaining carbon fraction.

A middle sized landfill bioreactor annually can be assumed to treat about 100000 ton of residual municipal waste. This amount of waste corresponds to approximately 25000 ton of organic carbon, or a fraction of approximately $15000 \times 10^{6} \mathrm{~g} \mathrm{C}$ each year which will be included in a long-lived fraction. This corresponds to about 45000 tons of carbon dioxide. The losses of organic carbon through the leachates only amount to a minor fraction. The long-lived carbon fraction accumulated in the fermentation residue thus corresponds to the total amount of carbon emitted per year from 12000 - 15000 cars per year, running approximately $15000 \mathrm{~km}$ per year and emitting approximately $212 \mathrm{~g} \mathrm{CO}_{2}$ per km. In addition to the accumulation of organic carbon resistant to mineralization, landfilling or treatment in reactor cells, also means an increasing amount of organic matter, which in spite of microbial degradation will be accumulated during a few years. Thus the positive effects on the carbon balance are not only related to the most long-lived fractions, which finally will be stored for a very long period of time.

[11] has, with another comparison, calculated that the deposition of organic matter in a medium sized controlled landfill ( 100000 tons per year) equals the total amount of carbon in approximately 65 hectares of grown-up spruce forest, or approximately 45 hectares of deciduous forest. It is of great importance to establish carbon accumulating functions in the urban society, as the natural $\mathrm{CO}_{2}$ balancing processes are insufficient to compensate for the increasing emissions of carbon dioxide.

Planting of an energy forest within a landfill area will also immobilize $\mathrm{CO}_{2}$ in standing biomass. In such a forest plantation, supplied by nutrients extracted from the waste in connection to utilization of leachates for irrigation, organic matter corresponding to approximately 10 tons of carbon can be stored in plant biomass per hectare each time unit, in spite of a short turn-over time for the produced biomass.

The accumulation in a landfill of organic carbon, which is resistant to anaerobic decay, e.g. derived from the lignine fraction of the waste, helps to retain water in the fermentation residue and maintain high moisture content. This will provide for a reliable long-term storage in the fermentation residue of heavy metals bound up as sulphides, which are insoluble under anoxic conditions. Thus, in the leachate mainly metals with a low atomic weight, as nutrients like sodium, potassium, magnesium and calcium, will occur together with nitrogen fractions. 
Thus, long-lived organic matter from landfilling of e.g. paper and wood products will act as a stabilizer for the landfill and immobilize toxic elements in a rather stable fermentation rest, which is left in the landfill. This chemical separation will open possibilities for nutrient separation and recovery through the utilization of the leachates as fertilizer in e.g. energy forests situated within the controlled landfill area. After burning of the biomass from the energy forest the ashes, containing most of the nutrients, will be used as a fertilizer or vitalizing agent in normal forestry. This in turn opens the possibilities to use a larger proportion of the logging residues from forests as a renewable fuel, decreasing the emissions of fossil $\mathrm{CO}_{2}$ even more. This circulation of nutrients will not be possible after waste incineration, as in this case the nutrients cannot easily be separated from toxic heavy metals, and the total amount of mixed ashes have to be long-term stored in landfills. Ashes from waste incineration mostly are classified as toxic waste.

Also other techniques for biological waste treatment producing compost or a bio-residue, where a fraction of the organic matter is rather resistant to degradation, are beneficial for the carbon dioxide balance. The use of such compost or bio-residue in sandy soils, or in soils with high clay content, will increase the humus concentration and thus the contents of organic carbon present in the soil.

\section{LEGAL POSSIBILITIES IN SWEDEN AND THE EU}

Sweden requires all its municipalities to draw up waste management plans with goals, strategies and action plans to secure an environmentally safe waste treatment. The intensions are to stimulate material recovery, mainly based on source separation and separate collection, but also different kinds of biological techniques to produce biogas and soil improvement. Due to difficulties to implement an effective system for material recovery and to establish enough demand from industry for the recovered material mass incineration has unfortunately increased. This is also the result of legislation, which is very unclear when it comes to biological treatment of residual wastes performed within the premises of a landfill. The laws related to restrictions on landfilling and waste taxes thus are interpreted differently among the county authorities in Sweden.

According to the decisions of the Swedish Parliament the restrictions on landfilling of organic or combustible waste should not disfavour the fermentation of residual wastes in bioreactor cells, even if these are constructed within landfill areas. As bioreactor cells are a form of biological waste treatment, it should not be subjected to limitations, like processing time, a.s.o., related to landfilling. Recently the Court of Appeal for environmental issues stated that treatment of residual waste in landfill reactor cells should be regarded as "biological treatment", and should be exempted from landfill tax. This will probably be a guideline for other waste treatment concessions concerning treatment of waste in biocells. This also opens the possibilities to regard fermentation in biocells and bioreactor cells as an in-situ pre-treatment of waste before final landfilling of a non-recyclable residual fraction.

In order to reduce the volume of residual waste, and to increase material recovery from wastes, focus is set on pre-sorting of material prior to treatment in a biocell reactor. In many countries, extensive scientific investigations have also shown that a sustained control of the emission and settlement behaviour of landfills through an anaerobic in situ stabilisation can eliminate negative environmental effects. By doing so, it serves two purposes, one being a process technology adapted to the conditions of the landfill body and operated in a qualified manner, and the other one being the long-term accumulation of e.g. lignin as well as fossil 
products that cannot be fully broken down by naturally occurring micro-organisms. Such a technology for long-term stability thus also compensates for carbon dioxide emissions.

Long-lived organic matter in landfills stabilizes, and will thus decrease the risk for leaching of toxic elements like heavy metals. Low concentrations of heavy metals in the leachates open the possibilities to use the leachates as fertilizer in e.g. energy forests, which will result in the production of wood chips which can be used as a renewable fuel, decreasing the emissions of fossil $\mathrm{CO} 2$ even more. If the ashes originated from forest biomass burning for energy are used as fertilizers in forestry, a larger proportion of the logging residues can also be used as a fuel. All these factors together will result in a potential supply of a $\mathrm{CO}_{2}$ neutral, renewable energy source, which would not be available if the waste was incinerated and the ashes, according to the legislation in most EU countries, were deposited in landfills for toxic waste.

During incineration of solid waste most of the organic carbon will be emitted as $\mathrm{CO}_{2}$, including carbon derived from fossil material. Due to high moisture content in municipal solid waste energy will be consumed and $\mathrm{CO}_{2}$ produced for the evaporation of water. This contributes to the negative effects of waste incineration on the atmospheric carbon balance. Incineration of wet waste also increases the risk for emissions of toxic organic pollutants in the stack gas emissions.

In Sweden the alternative to waste incineration for energy production would in most cases be combustion of woodchips or other renewable fuels, which, if not burned, anyhow would have had a short turn-over time. Thus burning of woodchips only has a small net effect on the global $\mathrm{CO}_{2}$ balance. With present political measures in Sweden, the alternative to waste incineration would not be burning of oil or coal. The realistic alternatives thus would give less emissions of fossil carbon to the atmosphere.

\section{CONCLUSIONS}

1. Landfilling of residual and contaminated fermentation residues, with a high concentration of organic matter, will produce a sink for organic carbon and will counteract increased atmospheric concentrations of $\mathrm{CO}_{2}$. If diffuse emissions of methane can be controlled and minimized, landfilling of organic matter has a positive effect also as a moderator of "global warming".

2. Landfilling is the recommended route for disposal of plastics, rubber and other products with a fossil origin, which no longer can be recycled through material recovery. Landfilling will return the carbon with fossil origin to long-term storage.

3. If energy production through mass incineration of residual waste was replaced by biological energy extraction from waste, and if bio fuels like straw or woodchips from forest residues or energy forests were used instead, the negative effects on the global carbon dioxide balance could be decreased.

4. Biocell fermentation of residual wastes should be regarded as a biological pretreatment technique, and the mostly biologically inert residues can be retained in a landfill without the risk for emissions of green-house gases.

5. In Sweden, with the present political and economical measures, the alternative to waste incineration would never be increased consumption of coal or oil for energy production. Instead, probably alternative energy sources like biogas, energy crops, forest residues or wind power would be of even more importance. 


\section{REFERENCES}

[1] IPCC, 2007. Climate Change 2007: The Physical Science Basis. Summary for Policymakers. Contribution of Working Group I to the Fourth Assessment Report of the Intergovernmental Panel on Climate Change. IPCC Secretariate, Geneva, Switzerland, $21 \mathrm{pp}$.

[2] Bramryd, T., 1982. Fluxes and accumulation of organic carbon in urban ecosystems on a global scale. - In Urban Ecology (Bornkamm, Lee and Seaward, eds.), Blackwell Scientific Publications, Oxford, 3-12.

[3] Bramryd T., 1983. Human impact on the biogeochemical cycling of carbon between terrestrial ecosystems and the atmosphere. Environmental Biogeochemistry. Ecol. Bull. (Stockholm) 35, 301-313.

[4] Bogner J., Spokas K., 1993. Landfill $\mathrm{CH}_{4}$ : Rates, fates, and role in global carbon cycle. - Chemosphere 26, 369-386.

[5] Bogner J., Spokas K., 1995. Carbon storage in landfills. In: Soils and Global Change. Advances in soil science. (Lal, Kimble, Levine and Stewart eds.). Chapter $\underline{5}$. , p 67-80. Lewis Publishers, Boca Raton, London, Tokyo.

[6] Binder M., Bramryd T., 2001. Comparison between former and present landfill techniques in respect to impacts on the environment. Water, Air \& Soil Pollution 129, 289-303.

[7] Barlaz M. A., Ham R. K., Schaefer D. M., 1989. Mass-balance analysis of anaerobically decomposed refuse. - J. Environmental Engineering Division ASCE 115, 1088-1102.

[8] SOU. 1996. Skatt på avfall. Slutbetänkande av Deponiskatteutredningen. Statens Offentliga utredningar, 1996:139. Finansdepartementet, Stockholm, 459 pp.

[9] Åkesson M.. 1997. Landfill ecosystem nutrition. - In: Biogas generation in landfills equilibrium, rates and yields. Doctoral Thesis Dept. of Water Resources Engineering, Lund University, Report 1018.

[10] Cossu R., Stegmann R., Acaia C., 1991. Treatment of vegetation water on layers of MSW organic fractions. In: Sardinia'91. Third International Landfill Symposium, pp 1461-1476, CISA (Environmental Sanitary Engineering Center), University of Cagliari, Sardinia.

[11] Bramryd T., Binder M., 2001. Landfill bioreactor cells as anaerobic filters for controlled extraction of bio-energy and nutrients from municipal solid wastes. The Environmentalist 21,297-303. 